\title{
Placental growth hormone, pituitary growth hormone, insulin-like growth factor, and ghrelin in umbilical cord blood serum and amniotic fluid
}

\author{
Hormon wzrostu łożyskowy, przysadkowy hormon wzrostu, insulinopodobny \\ czynnik wzrostu i grelina w surowicy krwi pępowinowej oraz w płynie owodniowym
}

\author{
Andrzej Kędzia', Elżbieta Petriczko' ${ }^{2}$, Agata Tarka ${ }^{3}$ \\ ${ }^{1}$ Department of Clinical Auxology and Paediatrics Nursing, Division of Diabetology and Obesity of the Developmental Age, Poznan \\ University of Medical Sciences, Poznan, Poland \\ ${ }^{2}$ Clinic of Paediatrics, Endocrinology, Diabetology, Metabolic Diseases and Cardiology of the Developmental Age, Pomeranian \\ Medical University, Szczecin, Poland \\ ${ }^{3}$ Institute of Practical Obstetrics Science, Poznan University of Medical Sciences, Poznan, Poland
}

\begin{abstract}
Introduction: In the search for biomarkers that allow the prediction of neonatal growth and development, placental growth hormone (PGH), pituitary growth hormone (GH1), insulin-like growth factor 1 (IGF-1), and ghrelin concentrations were assessed in the amniotic fluid and in the umbilical cord blood of 92 neonates.

Material and methods: The proteins were assayed by the ELISA method. Their concentration values were compared in 57 full-term neonates and 35 prematurely born neonates, as well as in both large $(>4,000 \mathrm{~g})$ and small neonates $(<2,500 \mathrm{~g})$. Also, body mass and placenta mass were compared.

Results: Statistically significant differences both between prematurely born neonates and full-term neonates and between large and small neonates were obtained only in terms of the body mass of neonates and placenta mass. The concentration values of the hormones studied did not show statistically significant differences. A distinct tendency was noticed towards an increase in PGH concentration in both prematurely born and small neonates. In large neonates, statistically significantly higher IGF-1 concentrations were found compared to the prematurely born neonates.

Conclusions: Our studies indicate an important role for PGH in maintaining a proper IGF-1 pool and demonstrate the existence of a direct influence on the function of the placenta in prematurely born neonates through the activation of compensation mechanisms, which stimulate IGF-1 synthesis. (Endokrynol Pol 2013; 64 (4): 293-298)
\end{abstract}

Key words: PGH, GH1, IGF-1, ghrelin, neonate, umbilical cord blood serum, amniotic fluid

\section{Streszczenie}

Wstęp: Poszukując czynników, które pozwoliłyby na prognozowanie dalszego rozwoju noworodka, oznaczano we krwi pępowinowej oraz w płynie owodniowym 92. noworodków stężenie łożyskowego hormonu wzrostu (PGH), przysadkowego hormonu wzrostu (GH1), insulinopodobnego czynnika wzrostu 1 (IGF-1) oraz greliny.

Materiał i metody: Omawiane białka były oznaczane metoda ELISA. Porównano wartości ich stężenia u 57. noworodków i 35. wcześniaków oraz u noworodków dużych (> 4000 g) i małych $(<2500$ g). Porównano również masę ciała noworodków i masę łożyska.

Wyniki: Statystycznie znamienne różnice pomiędzy wcześniakami i noworodkami donoszonymi oraz między dużymi i małymi dziećmi uzyskano jedynie w odniesieniu do masy ciała noworodków i masy łożyska. Natomiast wartości stężeń badanych hormonów nie wykazywały statystycznie znamiennych różnic. Zaobserwowano wyraźne tendencję wzrastania stężenia PGH u wcześniaków i noworodków małych. Natomiast u noworodków dużych uzyskano statystycznie znamienne wyższe stężenie IGF-1 w porównaniu z wcześniakami. Wnioski: Badania nasze wskazują na ważną rolę PGH w utrzymaniu odpowiedniej puli IGF-1 oraz bezpośredni wpływ na funkcję łożyska u wcześniaków poprzez uruchomienie mechanizmów kompensacyjnych stymulujących syntezę IGF-1. (Endokrynol Pol 2013; 64 (4): 293-298)

Stowa kluczowe: PGH, GH1, IGF-1, grelina, noworodek, surowica krwi pępowinowej, płyn owodniowy

This study was financed by grant no. N N407 200037.

\section{Introduction}

The proteins listed in the title belong to the group of growth and cell metabolism modulators. They are regu- lated by complexes of factors that act in systemic and local systems that differ in the pre- and postnatal periods. Growth processes are relatively well recognised in the postnatal phase, where the key endocrine factor

Andrzej Kędzia M.D. Ph.D., Department of Clinical Auxology and Paediatrics Nursing Division of Diabetology and Obesity of the Developmental Age Poznan University of Medical Sciences. Szpitalna St. 27/33, 60-572 Poznan, Poland, tel.: +4861 849 12 65, fax: +4861 8483362, e-mail: akedzia@ump.edu.pl 
controlling growth is the growth hormone 1/insulinlike growth factor 1 (GH1/IGF-1) axis [1]. Considerably less is known about the mechanisms controlling growth in foetal life in which IGF-1 does not work in conjunction with GH1 [2, 3].

The placental growth hormone is a product of the $\mathrm{GH}-\mathrm{V}$ gene; it is a member of a family of five growth hormone genes located on the long arm of chromosome 17. This hormone has been known since 1985, when it was discovered by Hennen et al. [4,5]. It shows a high level of homology to the pituitary growth hormone, being different in terms of 13 amino acids and N-glycosylation sites. This protein is synthesised and secreted by a syncytiotrophoblast and extravillous cytotrophoblast $[2,6,7]$. In their detailed review, Fuglsang and Ovesen [2] show that PGH seems to be only a maternal phenomenon. There are some publications describing the presence of this protein both in umbilical cord blood serum and amniotic fluid [8-10].

The aim of this study is an assessment of the concentrations of the studied proteins in umbilical cord blood serum and amniotic fluid. In addition, the authors have tried to determine if there is any relationship between the results obtained with neonate body mass and placenta mass, and the search for factors which would allow a child's development to be predicted.

\section{Material and methods}

Investigations were performed on umbilical cord blood and amniotic fluid samples. A total of 92 umbilical cord blood samples originating from one triplet pregnancy, 12 twin pregnancies and 79 singleton pregnancies were collected. The majority of the pregnancies were normal, eight pregnant women had type I diabetes (six type G1, one G2, and one type C). Among the 92 neonates, 52 boys and 40 girls were born. There were 35 infants born prematurely between weeks 22 and 37 of pregnancy, and 57 full-term neonates, born between weeks 37 and 42 .

Among the neonates, 33 weighed more than 4,000 $\mathrm{g}$ and 38 less than $2,500 \mathrm{~g}$.

All the neonates were examined by a neonatologist and weighed after birth; placenta mass was also measured. In four of the twin pregnancies, the placentas were common.

In neonate blood and amniotic fluid samples, the following hormones were assayed: pituitary growth hormone (GH1), placental growth hormone (PGH), insulin-like growth factor 1 (IGF-1) and acylated ghrelin.

Most of the amniotic fluids originated from amniocentesis: four fluids from weeks 14 and 15 of pregnancy, four fluids from week 17, two fluids from weeks 19 and 22, and two fluids collected during birth. A total of
12 amniotic fluids were collected from healthy pregnant women. All the investigated proteins were assayed using the ELISA method. GH1 and IGF-1 were assayed with R\&D Systems ELISA Kits (R\&D Systems, Minneapolis, MN, USA), PGH protein with a Uscn life Science ELISA Kit (Uscn life Science, Wuhan, China) and ghrelin was assayed with a BioVendor ELISA Kit (BioVendor, Modrice, Czech Republic), all according to the manufacturers' protocols. Briefly, the samples and standards were added as duplicates to micro-titration plates coated with antibodies against the studied substance. After incubation and washing, a secondary antibody was added, and the sample was incubated again. After subsequent washing, a colour reaction substrate, catalysed by a conjugated enzyme, was added. The reaction was stopped with $2 \mathrm{M}$ sulphuric acid. The plates were read in an MRX reader (Dynex, Chantilly, VA, USA). For statistical analysis, SigmaStat 3.5 software was used. The normality of the distribution of the variables was analysed with the Shapiro-Wilk method. For a comparison of the non-parametrical distributed variables, the Mann-Whitney Rank Sum Test was used; $p<0.05$ was considered statistically significant.

\section{Results}

As per the results presented in Table I, the median value for all the investigated factors was higher in full-term neonates than in prematurely born infants, except for PGH concentration, whose value was higher in prematurely born infants. Statistically significant differences between the two groups were shown only for neonate body mass and placenta mass. Concentrations of the investigated hormones did not show statistically significant differences. The highest mean values in full-term and prematurely born neonates were observed in IGF-1 concentrations $(87.5 \mathrm{ng} / \mathrm{mL}, 57.8 \mathrm{ng} / \mathrm{mL})$ and in pituitary growth hormone concentrations $(3,176.2 \mathrm{pg} / \mathrm{mL}, 2,886.5 \mathrm{pg} / \mathrm{mL})$.

During the analysis of particular cases, special attention was paid to the distinct tendency of PGH concentration to increase in small neonates compared to larger ones.

A similar situation was observed in the case of ghrelin concentrations. In some premature infants, ghrelin concentrations were higher than $100 \mathrm{pg} / \mathrm{mL}$, while in full-term neonates they were around $50 \mathrm{pg} / \mathrm{mL}$. However, in both cases, no statistically significant differences were observed. Besides, in five neonates (three prematurely born, two full-term infants), exceptionally low IGF-1 values, lower than $10 \mathrm{ng} / \mathrm{mL}$, were observed, and this is within the error limits.

Additionally, large ( $>4,000 \mathrm{~g})$ and small $(<2,500$ g) neonates were compared. The results are presented in Table II.

As per the results from Table II, statistically significant differences were shown for neonate body mass 
Table I. Minimal values, maximal values, and median of the investigated hormones concentrations in umbilical cord blood of full-term and premature born neonates; neonate and placenta mass

Tabela I. Wartości minimalne, maksymalne, mediana stężeń badanych hormonów we krwi pępowinowej noworodków donoszonych $i$ wcześniaków, masa ciała noworodków i łożyska

\begin{tabular}{|c|c|c|c|c|c|}
\hline \multirow[t]{2}{*}{ Investigated material } & \multicolumn{2}{|c|}{ Full-term neonate } & \multicolumn{2}{|c|}{ Prematurely born neonate } & \multirow[t]{2}{*}{ p value } \\
\hline & Min-max concentration & Median & Min-max concentration & Median & \\
\hline $\mathrm{GH} 1[\mathrm{pg} / \mathrm{mL}]$ & $937.8-8,131.6$ & $3,176.2$ & $882.2-13,358.3$ & $2,886.5$ & 0.946 \\
\hline PGH $[p g / m L]$ & $0-2,015.6$ & 346.9 & $106.4-1,728.7$ & 433.9 & 0.478 \\
\hline IGF I [ng/mL] & $10-132.2$ & 87.5 & $10-110.6$ & 57.8 & 0.184 \\
\hline Ghrelin [pg/mL] & $14.2-175.5$ & 70.5 & $14.3-184.5$ & 53.5 & 0.617 \\
\hline Neonate [g] & $1,790-5,430$ & 4,230 & $600-2,650$ & 1,770 & $<0.001$ \\
\hline Placenta [g] & $270-1,300$ & 700 & $150-900$ & 420 & $<0.001$ \\
\hline
\end{tabular}

Table II. Minimal values, maximal values, and median of the investigated hormones concentrations in umbilical cord blood of large $(>4,000 \mathrm{~g})$ and small $(<2,500 \mathrm{~g})$ neonates

Tabela II. Wartości minimalne, maksymalne, mediana badanych hormonów we krwi pępowinowej noworodków dużych, powyżej $4000 \mathrm{~g}$ i matych poniżej $2500 \mathrm{~g}$

\begin{tabular}{|c|c|c|c|c|c|}
\hline \multirow[t]{2}{*}{ Investigated material } & \multicolumn{2}{|c|}{ Neonate $>4,000 \mathrm{~g}$} & \multicolumn{2}{|c|}{ Neonate $<2,500 \mathrm{~g}$} & \multirow[t]{2}{*}{ p value } \\
\hline & Min-max concentration & Median & Min-max concentration & Median & \\
\hline $\mathrm{GH} 1[\mathrm{pg} / \mathrm{mL}]$ & $937.8-5,999.3$ & $3,117.3$ & $882.2-13,358.3$ & $2,891.9$ & 0.847 \\
\hline PGH $[\mathrm{pg} / \mathrm{mL}]$ & $0-2,015.6$ & 344.3 & $106.4-1,768.6$ & 396.6 & 0.386 \\
\hline IGF I [ng/mL] & $45.4-132.2$ & 98.9 & $10-110.6$ & 50.0 & $<0.001$ \\
\hline ghrelin [pg/mL] & $14.3-165.4$ & 75.4 & $14.3-184.5$ & 60.2 & 0.505 \\
\hline Neonate [g] & $4,000-5,430$ & 4,400 & $600-2,500$ & 1,840 & $<0.001$ \\
\hline Placenta [g] & $550-950$ & 720 & $150-1,300$ & 420 & $<0.001$ \\
\hline
\end{tabular}

and placenta mass. Higher IGF-1 concentrations in the blood serum of large neonates compared to small neonates was statistically significant. Moreover, as in Table I, higher PGH concentrations were recorded in small neonates than in large neonates.

The growth hormone concentration ratio was also evaluated: GH1/PGH, GH1/IGF-1, GH1/ghrelin, PGH/ IGF-1, PGH/ghrelin in the blood serum of full-term and prematurely born infants (Table III). In this table, the median of GH1 concentration in umbilical cord blood serum of full-term neonates was nine times higher than PGH, and six times higher than in prematurely born infants. The ratio of GH1 and IGF-1 concentrations in both investigated groups of neonates was similar and the IGF-1 concentration was about 25 times higher than GH1. The median IGF-1 concentration was 252 times higher than PGH in full-term neonates and 133 times higher in prematurely born infants. As for concentration ratio, there were no statistically significant differences between full-term and prematurely born neonates.

Similar to the results from Table 2 , a significant correlation in both investigated groups occurred between neonate body mass and placenta mass, and between GH1 and PGH in cord blood serum. Only full-term neonate body mass correlated with IGF-1 (Table IV).

Pituitary growth hormone concentration was the highest in second trimester amniotic fluid. PGH concentration was $50 \%$ lower, and the lowest concentrations were those of IGF-1 and ghrelin, and these were within error limits (Table V). In the amniotic fluid collected during the delivery, both growth hormone concentrations were several times lower than those for the second trimester of pregnancy.

\section{Discussion}

Our research showed that statistically significant differences in full-term and prematurely born neonates occurred only for neonate body mass and placenta mass. Median hormone concentration values for GH1, IGF-1, and ghrelin did not show statistically significant differences, and these were higher in full-term neonates and in the group of large infants $(>4,000 \mathrm{~g})$. This situation was different for PGH concentrations. The median 
Table III. Evaluation of the ratios of the investigated hormones from umbilical cord blood of full-term and prematurely born infants with median value. Hormone concentrations are presented in $\mathrm{pg} / \mathrm{mL}$

Tabela III. Ocena stosunku stężeń badanych hormonów z krwi pępowinowej noworodków donoszonych i wcześniaków z wykorzystaniem wartości mediany. Stężenia hormonów podano $\mathrm{w}[\mathrm{pg} / \mathrm{mL}]$

\begin{tabular}{|c|c|c|c|c|c|}
\hline \multirow{2}{*}{$\begin{array}{l}\text { Analysed hormones } \\
{[\mathrm{pg} / \mathrm{mL}]}\end{array}$} & \multicolumn{2}{|c|}{ Full-term neonates } & \multicolumn{2}{|c|}{ Prematurely born neonates } & \multirow[t]{2}{*}{$\mathrm{p}$ value } \\
\hline & Median & Concentration ratio & Median & Concentration ratio & \\
\hline $\mathrm{GH} 1 / \mathrm{PGH}$ & $3,176.2 / 346.9$ & $9: 1$ & $2,886.5 / 433.9$ & $7: 1$ & 0.940 \\
\hline GH1/IGF-1 & $3,176.2 / 87,500$ & $1: 28$ & $2,886.5 / 57,800$ & $1: 20$ & 0.146 \\
\hline GH1/ghrelin & $3,176.2 / 70.5$ & $45: 1$ & $2,886.5 / 53.5$ & $54: 1$ & 0.805 \\
\hline PGH/IGF-1 & $346.9 / 87,500$ & $1: 252$ & $433.9 / 57,800$ & $1: 133$ & 0.209 \\
\hline $\mathrm{PGH} /$ ghrelin & $346.9 / 70.5$ & $5: 1$ & $433.9 / 53.5$ & $8: 1$ & 0.542 \\
\hline
\end{tabular}

Table IV. Correlations between neonate birth weight and placenta mass, and the investigated hormones in cord blood serum Tabela IV. Korelacje pomiędzy masq ciała noworodków i masq̨ łożyska oraz badanymi hormonami we krwi pępowinowej

\begin{tabular}{lccc}
\hline Prematurely born infants & $\mathbf{r}$ & $\mathbf{p}$ & $\mathbf{n}$ \\
\hline Neonate birth weight and placenta mass & 0.574 & 0.001 & 32 \\
\hline Placenta mass and GH1 & 0.447 & 0.0152 & 29 \\
\hline GH1 and PGH & 0.388 & 0.0377 & 29 \\
\hline PGH and ghrelin & 0.365 & 0.0517 & 29 \\
\hline PGH and IGF-1 & -0.548 & 0.0325 & 15 \\
\hline Ghrelin and IGF-1 & -0.57 & 0.0252 & 15 \\
\hline Full-term neonates & $\mathrm{r}$ & $\mathrm{p}$ & 48 \\
\hline Neonate birth weight and placenta mass & 0.428 & 0.00255 & 25 \\
\hline Neonate birth weight and IGF-1 & 0.485 & 0.0141 & 48 \\
\hline GH1 and PGH & 0.341 & 0.0179 & 4 \\
\hline
\end{tabular}

Table V. Hormone concentration values in amniotic fluid

Tabela V. Wartości stężeń badanych hormonów w płynie owodniowym

\begin{tabular}{lcccc}
\hline Week of pregnancy & GH1 [pg/mL] & PGH [pg/mL] & IGF-1 [ng/mL] & Ghrelin [pg/mL] \\
\hline $14-15$ & 8,000 & $4,610.3$ & 28.2 & 8.3 \\
\hline 17 & 8,000 & $4,814.7$ & 27.4 & 8.4 \\
\hline $19-22$ & 8,000 & $1,699.9$ & 26.2 & 11.8 \\
\hline Collected during delivery & $1,446.2$ & 600 & 26.6 & 6 \\
\hline
\end{tabular}

value of this hormone concentration was higher in prematurely born and small neonates $(<2,500 \mathrm{~g})$, but the differences were not statistically significant (Table I and II). In the comparison of large and small infants (Table II), statistically significant differences also occurred in IGF-1 concentration. The median value of this hormone concentration was higher in large neonates. The placental growth hormone is synthesised by syncytiotrophoblast and secreted into the intervillous space. The presence of this hormone in the syncytiotrophoblast was confirmed with immunohistochemical methods [6]. Besides, with molecular methods GH-V gene expression was shown in the placenta, and no expression of the GH-N gene, responsible for GH1 production, was demonstrated [7, 11, 12]. Moreover, the presence of PGH receptors was detected in the placenta, and this suggests a direct influence of PGH on placenta function through auto- and paracrine mechanisms, 
which control the secretionary and proliferative activity of the placenta [13-15]. Higher PGH concentrations observed in prematurely born and small foetuses may indicate compensation mechanisms, in which elevated PGH secretion stimulates IGF-1 synthesis in placental tissue, which accelerates the proliferation and growth of placental tissue [6].

It seems that the foetal pituitary gland does not play an important role in those compensation processes. No GH-V gene expression was noted in the pituitary gland, and no GH-N gene transcript was detected in the placenta $[2,7,11,16,17]$. Furthermore, the median value of GH1 concentrations was similar in large and small neonates and also in full-term and prematurely born infants (Table I and II). By comparing concentrations of the particular proteins, we showed that IGF-1 concentration values in full-term neonates is 252 times higher compared to $\mathrm{PGH}$, and in prematurely born infants only 133 times higher (Table III). The IGF-1 to GH1 ratio of hormone concentrations was about 25 times higher and did not show higher differences in full-term and prematurely born neonates. These results enable us to suggest that PGH is an important modulator that maintains proper IGF-1 concentrations, and its secretion is not pulse. Chellakooty et al. [18] performed several examinations during pregnancy and showed a positive correlation between PGH concentration and foetal growth, as assessed by ultrasonography (USG). Our studies based on multivariate analysis indicate a positive correlation between neonate body mass and placenta mass in both investigated groups and also a correlation between full-term neonate body mass and IGF-1 concentration. In prematurely born infants, the correlation between PGH and IGF-1 concentrations was negative (Table IV). The results presented here and our suggestions require further investigations on a larger study group.

In terms of ghrelin concentrations, we have not shown statistically significant differences between full-term and prematurely born neonates, though in individual cases ghrelin concentrations were considerably higher in small neonates. Some authors have observed significantly higher concentration values for ghrelin in small neonates, but most researchers have not found any statistically significant differences [19-22]. Our previous research on human foetuses demonstrated that stimulation of GH1 secretion by ghrelin is independent of the feedback control and these two hormones act as a metabolic balance signal $[3,23]$. In adults, the hypothalamic pituitary axis regulates pulse secretion of $\mathrm{GH} 1$ from the pituitary gland, but in foetuses is not functionally mature before the third trimester of pregnancy, independent of earlier anatomical differentiation [3].
The very high concentration of PGH in amniotic fluid, about tenfold higher than in umbilical cord blood, is surprising. Perhaps PGH undergoes partial degradation in umbilical cord blood caused by the different time of delivery and there could be a problem with the collection of purified serum connected with this delivery. On the other hand, when comparing our results to the results of other researchers, the PGH concentrations in umbilical cord blood and amniotic fluid obtained by us are over three times higher. Sifakis et al. [10] observed high PGH concentrations in amniotic fluid in Down's syndrome pregnancies.

There is still no answer to the question as to how PGH, which is secreted by the syncytiotrophoblast, penetrates into the foetal circulation and amniotic fluid. A question arises as to whether the synthesis of this hormone also takes place in foetal cells. Finally, the recognition of the role of PGH in a foetal organism requires further thorough studies on a larger scale.

\section{Conclusion}

Our research indicates both an important role for PGH in maintaining the proper IGF-1 pool, and a direct influence on placenta functions through the activation of compensation mechanisms, which stimulate IGF-1 synthesis. The role of PGH in postnatal life, and its concentrations, particularly in the first months of life, is yet to be clarified. In the mother's organism this hormone undergoes a complete degradation after birth, and its fate in neonate blood is unknown. The trace concentration of IGF-1 in umbilical cord blood serum of five neonates, of whom three weighed less than 2,000 $\mathrm{g}$, is also unclear. Molecular studies in this area will be conducted in the future.

\section{References}

1. Kedzia A. Diagnostics of growth disorders and possibilities of treatment of short-stature children and adolescents in Wielkopolska. Poznan University Press, Poznan 2004.

2. Fuglsang J, Ovesen P. Aspects of placental growth hormone physiology. Growth Horm IGF Res 2006; 16: 67-85.

3. Kedzia A, Obara-Moszynska M, Chmielnicka-Kopaczyk M. Assessment of ghrelin, GHS-R, GH, and neurohormones in human fetal pituitary glands and central nervous system: an immunohistochemical study. Folia Histochem Cytobiol 2009; 47: 505-510.

4. Hennen G, Frankenne F, Pirens G et al. New chorionic GH-like antigen revealed by monoclonal antibody radioimmunoassays. Lancet 1985; (8425: 399.

5. Hennen G, Frankenne F, Closset J et al. A human placental GH: increasing levels during second half of pregnancy with pituitary $\mathrm{GH}$ suppression as revealed by monoclonal antibody radioimmunoassays. Int J Fertil 1985; 30: 27-33.

6. Lacroix MC, Guibourdenche J, Fournier T et al. Stimulation of human trophoblast invasion by placental growth hormone. Endocrinology 2005; 146: 2434-2444

7. Scippo ML, Frankenne F, Hooghe-Peters EL et al. Syncytiotrophoblastic localization of the human growth hormone variant mRNA in the placenta. Mol Cell Endocrinol 1993; 9: 7-13.

8. Mittal P, Espinoza J, Hassan S et al. Placental growth hormone is increased in the maternal and fetal serum of patients with preeclampsia. J Matern Fetal Neonatal Med 2007; 20: 651-659. 
9. Mittal P, Hassan SS, Espinoza J et al. The effect of gestational age and labor on placental growth hormone in amniotic fluid. Growth Horm IGF Res 2008; 18: 174-179.

10. Sifakis S, Papadopoulou E, Konstantinidou A et al. Increased levels of human placental growth hormone in the amniotic fluid of pregnancies affected by Down syndrome. Growth Horm IGF Res 2009; 19: 121-125.

11. Frankenne F, Rentier-Delrue F, Scippo ML et al. Expression of the growth hormone variant gene in human placenta. J Clin Endocrinol Metab 1987; 64: 635-637.

12. Liebhaber SA, Urbanek M, Ray J et al. Characterization and histologic localization of human growth hormone-variant gene expression in the placenta. J Clin Invest 1989; 83: 1985-1991.

13. Hill DJ, Riley SC, Bassett NS et al. Localization of the growth hormone receptor, identified by immunocytochemistry, in second trimester human fetal tissues and in placenta throughout gestation. J Clin Endocrinol Metab 1992; 75: 646-650.

14. Frankenne F, Alsat E, Scippo ML et al. Evidence for the expression of growth hormone receptors in human placenta. Biochem Biophys Res Commun 1992; 182: 481-486.

15. Silva CM, Kloth MT, Lyons CE et al. Intracellular signaling by growth hormone variant (GH-V). Growth Horm IGF Res 2002; 12: 374-380.

16. Jara CS, Salud AT, Bryant-Greenwood GD et al. Immunocytochemical localization of the human growth hormone variant in the human placenta. J Clin Endocrinol Metab 1989; 69: 1069-1072.
17. Lytras A, Bock ME, Dodd JG et al. Detection of placental growth hormone variant and chorionic somatomammotropin ribonucleic acid expression in human trophoblastic neoplasms by reverse transcriptase-polymerase chain reaction. Endocrinology 1994; 134: 2461-2467.

18. Chellakooty $M$, Vangsgaard $K$, Larsen $T$ et al. A longitudinal study of intrauterine growth and the placental growth hormone (GH)insulin-like growth factor I axis in maternal circulation: association between placental GH and fetal growth. J Clin Endocrinol Metab 2004; 89: 384-391.

19. Farquhar J, Heiman M, Wong AC et al. Elevated umbilical cord ghrelin concentrations in small for gestational age neonates. J Clin Endocrinol Metab 2003; 88: 4324-4327.

20. Onal EE, Cinaz P, Atalay Y et al. Umbilical cord ghrelin concentrations in small- and appropriate-for-gestational age newborn infants: relationship to anthropometric markers. J Endocrinol 2004; 180: 267-271.

21. Pirazzoli P, Lanari M, Zucchini S et al. Active and total ghrelin concentrations in the newborn. J Pediatr Endocrinol Metab 2005; 18: 379-384.

22. Bellone S, Rapa A, Vivenza D et al. Circulating ghrelin levels in the newborn are positively associated with gestational age. Clin Endocrinol 2004; 60: 613-617.

23. Kedzia A, Obara-Moszynska M, Chmielnicka-Kopaczyk M. Immunohistochemical assessment of ghrelin, GHS-R, GH, GHRH and somatostatin in pituitary glands of human fetuses. Arch Perinat Med 2007; 13: 44-48. 